\author{
Joanna M. MOCZYDLOWSKA \\ Lukasz SADOWSKI ${ }^{2}$
}

\title{
ZACHOWANIA NIEETYCZNE W PRAKTYCE ZARZĄDZANIA W PERCEPCJI MENEDŻERÓW
}

\begin{abstract}
Artykuł opiera się na założeniu, że zachowanie zgodne z zasadami etyki biznesu należy do kluczowych kompetencji profesjonalnego menedżera. Uznano, że jednym z warunków kształtowania wrażliwości etycznej najwyższej kadry kierowniczej jest jej świadomość dotycząca występowania zjawisk dwuznacznych lub wręcz nagannych moralnie w przedsiębiorstwach. Celem badań prezentowanych w artykule jest rozwiązanie następującego problemu: jakie zachowania nieetyczne dostrzegają menedżerowie w środowisku biznesowym? Aby rozwiązać tak sformułowany problem przeprowadzono badania ankietowe w grupie menedżerów - absolwentów studiów MBA prowadzonych przez Instytut Nauk Ekonomicznych Polskiej Akademii Nauk w Warszawie. Badania traktujemy jako pilotażowe, a ich wyniki jako podstawę do budowania hipotez do dalszych, pogłębionych badań naukowych. Z badań wynika, że w relacjach z zewnętrznymi partnerami biznesowymi najczęstszymi zachowaniami nieetycznymi są: niepełna i nierzetelna komunikacja w celu uzyskania szybkich korzyści oraz szeroko rozumiana nieuczciwa konkurencja i brak dbałości o ochronę środowiska naturalnego. Jako najczęściej występujace zachowania nieetyczne $\mathrm{w}$ relacjach $\mathrm{z}$ interesariuszami wewnętrzni badani wskazali wykorzystywanie bezrobocia do utrzymywania niskiego poziomu wynagrodzeń, nepotyzm i różne formy dyskryminacji. Dylematy etyczne najwyższej kadry kierowniczej wynikają przede wszystkim z potrzeby pogodzenia „presji na twarde wyniki” z humanistycznym wymiarem zarządzania. Stwierdzono również, że menedżerowie są bardziej wrażliwi na kwestie etyki postępowania $\mathrm{w}$ relacjach $\mathrm{z}$ pracownikami niż z podmiotami zewnętrznymi, w tym klientami i dostawcami.

Słowa kluczowe: etyka, dylematy etyczne, percepcja menedżerów.
\end{abstract}

\section{WPROWADZENIE}

Od osób zarządzających organizacją wymaga się wrażliwości etycznej, która stanowi oparcie w rozstrzyganiu konkretnych sytuacji konfliktowych, a także budowania kompleksowej kultury organizacji opartej na uniwersalnych wartościach. Wartością centralną etyki zawodowej menedżerów jest sprawność organizacyjna i funkcjonalność, które wspomagają osiąganie celu, a jest nim dobro wspólne, czyli dobro własne i cudze. I choć, jak twierdzą niektórzy badacze problemu ${ }^{3}$, idealne etycznie postępowanie wydaje się w przypadku menedżerów niemożliwe, to jednak ci sami przedstawiciele nauk o zarządzaniu podkreślają, że brak etycznego zarządzania organizacją powoduje szkody nie tylko dla interesariuszy tej organizacji, ale także dla niej samej.

\footnotetext{
${ }^{1}$ Dr hab. Joanna M. Moczydłowska prof. PB, Wydział Zarządzania Politechniki Białostockiej Wydział Zarządzania, ul. Ojca Tarasiuka 2, 16-001 Kleosin, e-mail: joanna@moczydlowska.pl ${ }^{2}$ Łukasz Sadowski, MBA, INE PAN Warszawa

${ }^{3}$ Por. A. Rogowski, Etyka menedżerów w funkcjach zarządzania, „Przedsiębiorstwo Przyszłości” 2014, nr 3 (20), s. 44.
} 
Artykuł zawiera wyniki analizy literatury dotyczącej problematyki etyki w postawach zawodowych menedżerów oraz wyniki badań kwestionariuszowych przeprowadzonych na próbie 93 przedstawicieli najwyższej kadry kierowniczej. Celem badań było zdiagnozowanie, jakie zachowania nieetyczne dostrzegają menedżerowie w środowisku biznesowym, zarówno $\mathrm{w}$ relacjach $\mathrm{z}$ podmiotami zewnętrznymi, jak i wewnątrz organizacji.

\section{ETYKA ZAWODOWA MENEDŻERÓW -TLO TEORETYCZNE PROBLEMU}

Poprzez etykę W zarządzaniu rozumie się ogół norm, którymi kierują się menedżerowie w swojej codziennej pracy. Innymi słowy etyka menedżera to etyka indywidualna sprowadzona do odpowiedzialności jednostkowej za podejmowane decyzje w realizowaniu funkcji zarządzania. Etyczność zachowań jest warunkowana poprzez wiele czynników. Do najważniejszych zalicza się kulturę organizacji, osobowość menedżera, ale także cechy otoczenia. Można ostrożnie przyjąć, że menedżerowie mają obecnie świadomość, że ich praca oceniana jest nie tylko w kategoriach ekonomicznych, na przykład zysku osiąganego przez zarządzane przez nich przedsiębiorstwa, ale w znacznie szerszym wymiarze, w który wpisuje się postawa etyczna. Mówi się wręcz o etycznym modelu zarządzania, w którym mocno eksponowany jest etyczny kontekst osiągania celów przedsiębiorstwa ${ }^{4}$. Podkreśla się znaczenie trwałych relacji ze wszystkimi interesariuszami organizacji, a te z kolei muszą być oparte na zaufaniu zbudowanym na fundamencie otwartości, szczerości, transparentności i uczciwości oraz wzajemnym szacunku. Realizacja etycznego modelu zarządzania w dłuższej perspektywie czasowej pozwala na zbudowanie przewagi konkurencyjnej. Uwzględnianie przez menedżerów dobra grup społecznych współpracujących bezpośrednio lub pośrednio $\mathrm{z}$ przedsiębiorstwem jest cenniejsze od tymczasowych wyższych zysków, bo taka postawa procentuje w przyszłość przekładając się na dobry wizerunek organizacji, wzrost zaangażowania i lojalności pracowników, a także rosnące zainteresowanie inwestorów ${ }^{5}$.

Diagnoza postaw menedżerów wobec problematyki etycznej pozwala wyodrębnić kilka ich typów ${ }^{6}$. Pierwszy $\mathrm{z}$ nich to ignorancja. Menedżerowie reprezentujący taką postawę nie widzą potrzeby analizy swoich działań zarządczych pod kątem etycznym. Promują ideę, w myśl której jedynym punktem odniesienia ich działań jest prawo, a zatem przestrzeganie przepisów prawa całkowicie wyczerpuje ich powinności w tym zakresie. Działają oni według zasady: co nie jest zabronione prawem, jest dozwolone. Regułę tę stosują zarówno wobec swoich podwładnych, jak i wobec innych grup interesariuszy. Kolejna grupa to menedżerowie prezentujący postawę wycofania. Doceniają oni wagę norm etycznych, uważają jednak, że ich stosowanie dotyczy wyłącznie sfery życia prywatnego, a firma nie stanowi przestrzeni praktykowania etyki. Stosunkowo często za taką postawą kryje się brak kompetencji menedżerów, którzy nie wiedzą, w jaki sposób mogliby - bez ryzyka utraty autorytetu - współtworzyć i promować wartości etyczne.

\footnotetext{
${ }^{4}$ K. Mulawa, O etycznych wyzwaniach menedzera, Uniwersytet Wrocławski, Wrocław 2014.

5 A. Wykowski, Społeczna odpowiedzialność biznesu gwarancja sukcesu przedsiębiorstwa, „Zeszyty Naukowe Uniwersytetu Przyrodniczo-Humanistycznego w Siedlcach” 2013, nr 98, s. 288291.

6 J. Moczydłowska, Etyczny kontekst przywództwa organizacyjnego, „Dyskusje o Zarządzaniu” 2015, nr 5, s. 82-85.
} 
Najbardziej wartościowa wydaje się postawa zaangażowania. Reprezentujący ją menedżerowie bardzo poważnie traktują etyczny kontekst swojej pracy, a także pracy całej organizacji. Stawiają pytania o to, jakie reguły etyczne powinny obowiązywać w organizacji? Z jakimi problemami i dylematami etycznymi mamy do czynienia? W budowaniu relacji stawiają na partnerstwo i współdziałanie odrzucając wizję siłowego narzucania rozwiązań.

Z powyższych rozważań wynika, że kształtowanie etyki w zarządzaniu wymaga przemyślanej edukacji etycznej, ponieważ jak zauważa A. Lewicka-Strzałecka, „do moralnej oceny wielu decyzji w biznesie nie wystarczy sama uczciwość, chęć czynienia dobra [...]. Działanie etyczne jest nie tylko kwestią wrażliwości czy intuicji moralnej, lecz wiedzy",

\section{METODYKA BADAŃ WLASNYCH}

Celem badań prezentowanych $\mathrm{w}$ tym artykule jest rozwiązanie następującego problemu: jakie zachowania nieetyczne dostrzegają menedżerowie w środowisku biznesowym? Aby rozwiązać tak sformułowany problem przeprowadzono badania w grupie menedżerów - absolwentów studiów Executive MBA prowadzonych przez Instytut Nauk Ekonomicznych Polskiej Akademii Nauk. Uzyskano zwrot 93 kwestionariuszy. Mimo, że badana próba była bardzo zróżnicowana pod względem stażu pracy na stanowisku kierowniczym czy branży, uznajemy, że liczba ankiet jest zbyt mała, aby na ich podstawie formułować mocne wnioski. Dlatego badania traktujemy jako pilotażowe, a ich wyniki jako podstawę do budowania hipotez do dalszych, pogłębionych badań naukowych.

Należy podkreślić fakt, że problem standardów etycznych w pracy zawodowej menedżera należy do kwestii wrażliwych. Zdecydowana większość ludzi postrzega siebie jako osoby etyczne, a ewentualne przejawy nieetyczności tłumaczy stosując różnorodne mechanizmy obronne, zwłaszcza racjonalizację opartą na relatywizmie etycznym. Dlatego w kwestionariuszu nie pytano wprost o zachowania badanych, ale o ich opinie dotyczące problemów etycznych występujących w reprezentowanym przez nich środowisku.

W badanej grupie dominowali mężczyźni (65\%). Ponad połowa respondentów (56\%) pracuje na wysokim stanowisku kierowniczym więcej niż 5 lat.

\section{WYNIKI BADAŃ}

Badani menedżerowie zostali poproszeni o ocenę częstotliwości występowania zachowań nieetycznych $\mathrm{w}$ ich kontaktach biznesowych $\mathrm{z}$ podmiotami zewnętrznymi. Rozkład odpowiedzi zawiera tabela 1 .

\footnotetext{
${ }^{7}$ A. Lewicka-Strzałecka, Poznawczy model kształcenia etycznego: studium przypadku [w:] Etyka biznesu jako przedmiot nauczania, red. W. Gasparski, A. Lewicka-Strzałecka, Warszawa 2001, s. 125 .
} 
Tabela 1. Zachowania nieetyczne, z którymi spotkali się respondenci podczas współpracy $\mathrm{z}$ podmiotami zewnętrznymi

\begin{tabular}{|l|c|c|c|c|c|c|c|c|c|c|}
\hline \multirow{2}{*}{ Kategoria odpowiedzi } & \multicolumn{2}{|c|}{ bardzo rzadko } & \multicolumn{2}{|c|}{ rzadko } & \multicolumn{2}{c|}{$\begin{array}{l}\text { ani rzadko/ani } \\
\text { często }\end{array}$} & \multicolumn{2}{|c|}{ często } & \multicolumn{2}{c|}{ bardzo często } \\
\cline { 2 - 12 } & $\%$ & Liczba & $\%$ & Liczba & $\%$ & Liczba & $\%$ & Liczba & $\%$ & Liczba \\
\hline $\begin{array}{l}\text { niepełna i nierzetelna } \\
\text { komunikacja celem } \\
\text { uzyskania chwilowych } \\
\text { korzyści }\end{array}$ & 11,8 & 11 & 21,5 & 20 & 23,7 & 22 & 37,6 & 35 & 5,4 & 5 \\
\hline $\begin{array}{l}\text { nieuczciwa konkurencja } \\
\text { (szeroko rozumiana) }\end{array}$ & 13,9 & 13 & 17,2 & 16 & 27,9 & 26 & 33,3 & 31 & 7,5 & 7 \\
\hline $\begin{array}{l}\text { oferowanie } \\
\text { i przyjmowanie korzyści } \\
\text { majątkowych }\end{array}$ & 30,11 & 28 & 25,81 & 24 & 17,2 & 16 & 23,7 & 22 & 3,2 & 3 \\
\hline $\begin{array}{l}\text { brak dbałości } \\
\text { o zapewnienie } \\
\text { bezpieczeństwa } \\
\text { sprzedawanych } \\
\text { towarów/usług }\end{array}$ & 22,6 & 21 & 31,2 & 29 & 25,8 & 24 & 16,1 & 15 & 4,3 & 4 \\
\hline $\begin{array}{l}\text { niesprawiedliwe zasady } \\
\text { przy doborze dostawców }\end{array}$ & 13,9 & 13 & 29 & 27 & 27,9 & 26 & 25,8 & 24 & 3,2 & 3 \\
\hline $\begin{array}{l}\text { wywieranie wpływu na } \\
\text { instytucje publiczne }\end{array}$ & 24,7 & 23 & 31,2 & 29 & 25,8 & 24 & 13,9 & 13 & 4,3 & 4 \\
\hline $\begin{array}{l}\text { brak dbałości o ochronę } \\
\text { środowiska naturalnego }\end{array}$ & 19,3 & 18 & 19,3 & 18 & 23,7 & 22 & 30,1 & 28 & 7,5 & 7 \\
\hline
\end{tabular}

Źródło: opracowanie własne na podstawie wyników badań ankietowych.

Z badań wynika, że najczęściej obserwowanym zjawiskiem wyraźnie wykraczającym poza standardy etyki biznesu jest niepełna i nierzetelna komunikacja w celu uzyskania szybkich korzyści. Wskazuje na nią ponad 43\% respondentów. W ocenie badanych menedżerów istotnym problemem jest również szeroko rozumiana nieuczciwa konkurencja. Jako zjawisko częste lub bardzo częste wskazało na nią aż 41\% badanych, a blisko $28 \%$ badanej próby uważa, że stopień natężenia tego problemu należy ocenić jako przeciętny. Menedżerowie zwrócili również uwagę na brak dbałości o ochronę środowiska naturalnego (opinię taką wyraziło blisko 40\% badanych). Znamienne jest, że w ocenie blisko 1/4 respondentów często, a nawet bardzo często mają miejsce także różnego rodzaju praktyki korupcyjne, a więc zachowania niezgodne nie tylko z normami etycznymi, ale także prawnymi. Nie stwierdzono istotnych statystycznie różnic między wypowiedziami kobiet i mężczyzn. 


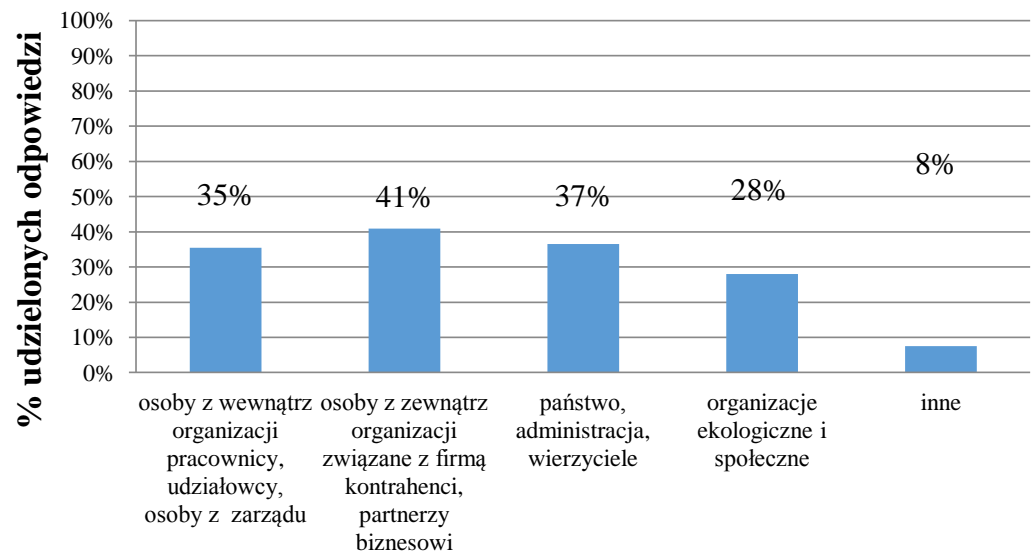

Rys. 1. Podmioty wskazane jako te, z którymi współpraca obciążona jest największym ryzykiem zachowań nieetycznych

Źródło: opracowanie własne na podstawie wyników badań ankietowych.

Badania nie pozwoliły na wyłonienie jakiejś konkretnej grupy podmiotów, z którymi w ocenie menedżerów - najtrudniej współpracować przestrzegając kodeksów etycznych (por. rys. 1). Nieznacznie częściej wskazywane były podmioty zewnętrzne współpracujące z przedsiębiorstwem (kontrahenci, partnerzy biznesowi).

W badaniu podjęto problem częstotliwości występowania zachowań nieetycznych wewnątrz organizacji, czyli $\mathrm{w}$ relacjach $\mathrm{z}$ interesariuszami wewnętrznymi. Rozkład odpowiedzi przedstawiono w tabeli 2 .

Tabela 2. Przejawy zachowań nieetycznych w relacjach wewnątrz przedsiębiorstwa oraz na linii pracownik - pracodawca

\begin{tabular}{|l|c|c|c|c|c|c|c|c|c|c|}
\hline \multirow{2}{*}{$\begin{array}{c}\text { Kategoria } \\
\text { odpowiedzi }\end{array}$} & \multicolumn{2}{|c|}{ bardzo rzadko } & \multicolumn{2}{c|}{ rzadko } & \multicolumn{2}{c|}{$\begin{array}{c}\text { ani rzadko/ani } \\
\text { często }\end{array}$} & \multicolumn{2}{c|}{ często } & \multicolumn{2}{c|}{ bardzo często } \\
\cline { 2 - 12 } & $\%$ & Liczba & $\%$ & Liczba & $\%$ & Liczba & $\%$ & Liczba & $\%$ & Liczba \\
\hline $\begin{array}{l}\text { nepotyzm (podczas } \\
\text { procesu rekrutacji) }\end{array}$ & 12,8 & 12 & 24,5 & 23 & 21,3 & 20 & 34 & 32 & 7,4 & 7 \\
\hline $\begin{array}{l}\text { różne przejawy } \\
\text { dyskryminacji, np. } \\
\text { ze względu na płeć, } \\
\text { wiek }\end{array}$ & 24,5 & 23 & 26,6 & 25 & 15,9 & 15 & 26,6 & 25 & 6,4 & 6 \\
\hline $\begin{array}{l}\text { mobbing } \\
\text { mynnagrodzenie } \\
\text { nieadekwatne do } \\
\text { wykonywanej } \\
\text { pracy }\end{array}$ & 4,3 & 4 & 15,9 & 15 & 21,3 & 20 & 44,7 & 42 & 13,8 & 13 \\
\hline
\end{tabular}




\begin{tabular}{|l|c|c|c|c|c|c|c|c|c|c|}
$\begin{array}{l}\text { nadmierna kontrola } \\
\text { pracownika / } \\
\text { możliwość } \\
\text { przekraczania } \\
\text { granic prywatności }\end{array}$ & 17 & 16 & 27,7 & 26 & 25,5 & 24 & 26,6 & 25 & 3,2 & 3 \\
\hline $\begin{array}{l}\text { konflikt interesów } \\
\text { w relacji firma } \\
\text { pracownik }\end{array}$ & 9,6 & 9 & 29,8 & 28 & 26,6 & 25 & 28,7 & 27 & 5,3 & 5 \\
\hline $\begin{array}{l}\text { niski poziom } \\
\text { lojalności } \\
\text { i uczciwości } \\
\text { względem firmy }\end{array}$ & 6,4 & 6 & 26,6 & 25 & 25,5 & 24 & 36,2 & 34 & 5,3 & 5 \\
\hline
\end{tabular}

Źródło: opracowanie własne na podstawie wyników badań ankietowych.

Problemem, który zdaniem uczestników badania występuje najczęściej w polskich przedsiębiorstwach $\mathrm{w}$ relacjach $\mathrm{z}$ interesariuszami wewnętrznymi jest nieadekwatne wynagradzanie pracowników. Słusznie za nieetyczne uznano wykorzystywanie zjawiska bezrobocia do utrzymywania relatywnie niskiego poziomu wynagrodzeń. W ocenie ponad $41 \%$ respondentów na szeroką skalę występuje zjawisko nepotyzmu, a ponad $30 \%$ respondentów (głównie kobiety) dostrzega problem różnych form dyskryminacji, np. ze względu na wiek czy płeć. Także 30\% badanych dostrzega zjawisko nadmiernej kontroli pracowników, która może przybrać formę przekraczania granic prywatności. Paradoksalnie za zjawisko stosunkowo rzadkie uznano mobbing. W ocenie menedżerów problemem, z którym borykają się przedsiębiorstwa jest również niski poziom lojalności i uczciwości pracowników, co bez wątpienia może pociągać za sobą zachowania etycznie naganne.

Uczestniczący w badaniu menedżerowie zostali poproszeni o wskazanie najtrudniejszych, ich zdaniem, dylematów etycznych, z którymi osobiście borykają się w swojej pracy zawodowej. W celu ujednolicenia formy prezentacji wyników ujmujemy je w formie pytań. Kategorie wypowiedzi przedstawiano w tabeli 3.

Tabela 3. Dylematy etyczne w praktyce zawodowej badanych

\begin{tabular}{|l|l|l|}
\hline \multicolumn{1}{|c|}{ Kategoria odpowiedzi } & Liczba & $\%$ \\
\hline $\begin{array}{l}\text { Jak zapewnić pracownikom work-life-balance i zadbać, aby się nie } \\
\text { wypalili zawodowo, kiedy w korporacji jest ciągła presja na realizację } \\
\text { ambitnych celów? }\end{array}$ & 36 & 38,7 \\
\hline $\begin{array}{l}\text { Czy zwalniać pracowników nie realizujących zakładanego poziomu } \\
\text { budżetu firmy wiedząc o trudnej sytuacji życiowej pracownika? }\end{array}$ & 29 & 31,2 \\
\hline $\begin{array}{l}\text { Czy dążyć do jak największej zyskowności kosztem jakości, } \\
\text { bezpieczeństwa produktów, warunków pracy pracowników i dostawców? }\end{array}$ & 29 & 31,2 \\
\hline Czy, podobnie jak konkurencja, ,podkupować” kluczowych pracowników? & 25 & 26,9 \\
\hline Czy bez zwiększania pensji pracownikowi zwiększać zakres obowiązków? & 24 & 25,8 \\
\hline $\begin{array}{l}\text { Jak stosować standardy etyczne, gdy jest się osamotnionym i wszyscy } \\
\text { wokoło włącznie z przełożonymi ich nie stosują? }\end{array}$ & 17 & 18,3 \\
\hline $\begin{array}{l}\text { Jak realizować coraz wyżej postawione plany i jednocześnie utrzymaćc } \\
\text { wysoką motywację pracowników? }\end{array}$ & 17 & 18,3 \\
\hline $\begin{array}{l}\text { Czy inwestować w pracownika, u którego występuje ryzyko odejścia do } \\
\text { konkurencji? }\end{array}$ & 9 & 9,7 \\
\hline Czy poddać się korupcji w zamian za korzystne rozstrzygnięcia? & 8 & 8,6 \\
\hline
\end{tabular}




\begin{tabular}{|l|l|l|}
\hline $\begin{array}{l}\text { Jak radzić sobie z pracownikami, którzy osiągają ponadprzeciętne wyniki } \\
\text { w pracy, ale swoim zachowaniem nie wpisując się w obowiązujący kodeks } \\
\text { etyczny? }\end{array}$ & 8 & 8,6 \\
\hline $\begin{array}{l}\text { Jak egzekwować realizację zadań od osoby która została zatrudniona } \\
\text {,z polecenia” przełożonego i ma być „specjalnie traktowana”? }\end{array}$ & 8 & 8,6 \\
\hline Czy zataić fakty, aby uzyskać korzyści? & 7 & 7,5 \\
\hline $\begin{array}{l}\text { Jak sprawiedliwie traktować pracowników, jak oddzielić sympatię do } \\
\text { człowieka od oceny jego kompetencji zawodowych? }\end{array}$ & 7 & 7,5 \\
\hline Ile informacji pochodzących od zarządu przekazywać pracownikom? & 6 & 6,4 \\
\hline Inne & 6 & 6,4 \\
\hline
\end{tabular}

Źródło: opracowanie własne na podstawie wyników badań ankietowych.

Z danych zawartych $\mathrm{w}$ tabeli 3 wynika, że najważniejsze dylematy natury etycznej, których doświadczają menedżerowie dotyczą ich relacji wewnątrz organizacji, a zwłaszcza relacji $\mathrm{z}$ pracownikami. Dominują problemy wynikające $\mathrm{z}$ potrzeby pogodzenia ,presji na twarde wyniki” $z$ humanistycznym wymiarem zarządzania. Kwestie związane $\mathrm{z}$ motywowaniem pracowników, sprawiedliwą organizacją ich pracy, zwolnieniami czy inwestowaniem w rozwój kadr należy uznać za najbardziej istotne w kontekście etyki zarządzania. Prawdopodobnie wynika to nie tylko z rosnącej świadomości menedżerów, że zadowolony pracownik jest bardziej lojalny, zaangażowany, a co się z tym wiąże, bardziej efektywny w swojej pracy. Pracownicy to ludzie, z którymi menedżerowie mają bezpośredni, często codzienny kontakt, co zwykle przekłada się na więzi natury emocjonalnej. Trudniej jest zachowywać się nieetycznie wobec osób, z którymi pozostaje się w tego rodzaju związkach.

\section{ZAKOŃCZENIE}

Świat współczesnych organizacji potrzebuje etycznych przedsiębiorców i menedżerów. Etyka tej grupy zawodowej wpływa na profesjonalizację i prestiż samego zawodu, tworzy pozytywny image nowoczesnego przedsiębiorcy, pomaga w rozwiązywaniu konfliktów i przyspiesza proces decyzyjny. Każdy, kto traci tę perspektywę nie może aspirować do miana profesjonalnego menedżera. $Z$ przedstawionych $\mathrm{w}$ tym artykule badań wynika, że świadomość różnorodnych nieetycznych zachowań w biznesie jest $\mathrm{w}$ środowisku menedżerów wysoka. Trzeba jednocześnie podkreślić, że sama świadomość nie gwarantuje wyeliminowania czy choćby zmniejszenia skali problemu. Stwarza jednak taką szansę.

Przeprowadzone badania pozwalają na sformułowanie następujących hipotez:

- w relacjach z zewnętrznymi partnerami biznesowymi najczęściej obserwowanym zjawiskiem wyraźnie wykraczającym poza standardy etyki biznesu jest niepełna i nierzetelna komunikacja w celu uzyskania szybkich korzyści oraz szeroko rozumiana nieuczciwa konkurencja i brak dbałości o ochronę środowiska naturalnego;

- do najczęściej występujących zachowań nieetycznych w relacjach z interesariuszami wewnętrzni należy wykorzystywanie bezrobocia do utrzymywania niskiego poziomu wynagrodzeń, nepotyzm i różne formy dyskryminacji; 
- dylematy etyczne najwyższej kadry kierowniczej wynikają przede wszystkim z potrzeby pogodzenia ,presji na twarde wyniki” z humanistycznym wymiarem zarządzania;

- menedżerowie są bardziej wrażliwi na kwestie etyki postępowania w relacjach z pracownikami niż z podmiotami zewnętrznymi, w tym klientami i dostawcami.

\section{LITERATURA}

[1] Lewicka-Strzałecka A., Poznawczy model kształcenia etycznego: studium przypadku [w:] Etyka biznesu jako przedmiot nauczania, red. W. Gasparski, A. Lewicka-Strzałecka, Wyższa Szkoła Przedsiębiorczości i Zarządzania im. L. Koźmińskiego w Warszawie, Warszawa 2001.

[2] Moczydłowska J., Etyczny kontekst przywództwa organizacyjnego, „Dyskusje o Zarządzaniu" 2015, 5, s. 21-23.

[3] Mulawa K., O etycznych wyzwaniach menedżera, Uniwersytet Wrocławski, Wrocław 2014.

[4] Rogowski A. Etyka menedżerów w funkcjach zarządzania, „Przedsiębiorstwo Przyszłości” 2014, 3 (20): 44-53.

[5] Wykowski A., Spoleczna odpowiedzialność biznesu gwarancją sukcesu przedsiębiorstwa, Zeszyty Naukowe Uniwersytetu Przyrodniczo-Humanistycznego w Siedlcach, 98, Siedlce 2013, s. 287-295.

\section{UNETHICAL BEHAVIOURS IN MANAGEMENT PRACTICE FROM}

\section{MANAGERS' PERCEPTION}

The article is based on assumption that the behavior consistent with business ethic's principles belongs to the key competences of the professional manager. It has been acknowledged that one of the conditions of forming managerial staff's ethical sensitivity is their awareness relevant to ambiguous or even morally reprehensible phenomenon's occurrence in the enterprises. The aim of the research presented in the article is to solve the following problem: What unethical behaviors are detected by managers in the business environment? The survey research among the managers who are graduate of MBA run by Polish Academy of Sciences in Warsaw has been conducted to solve so worded problem. The following conclusion can be drawn from the research: in relations with business partners from the outside the most frequent unethical behaviors are: incomplete and nonsolid communication in order to draw quick benefits, widely understood unfair competition and also lack of protection of natural environment's care. The survey participants marked using unemployment for keeping low salary level, the nepotism and various forms of the discrimination as the most frequent unethical behaviors in relations with the interoffice stakeholders. The managerial staff's ethical dilemmas primarily come from need of reconciling 'pressure on the hard outcome' with humanistic dimension of the management. It has been also affirmed that the managers are more sensitive to issue of behavioral ethics in relations with the employees than persons from the outside, including clients and suppliers.

Keywords: ethics, ethical dilemmas, perception managers.

DOI:10.7862/rz.2017.hss.11

Przesłano do redakcji: styczeń 2017 r.

Przyjęto do druku: marzec 2017 r. 